
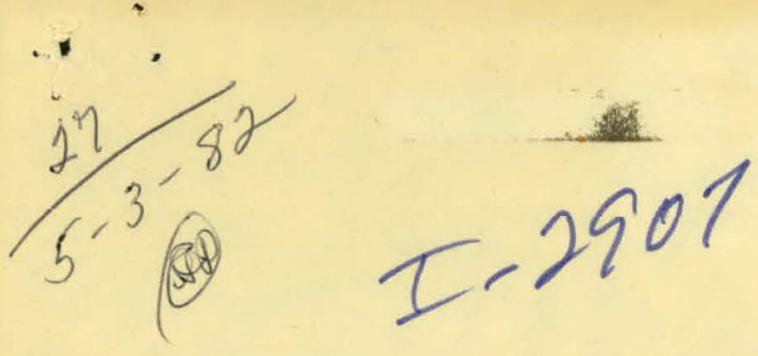

SERI/TP-235-1582

UC Category: 61 a

SERI/TP--235-1582

DE82 013565

\title{
Dissociated Methanol Test Results
}

Joseph G. Finegold

J. Thomas McKinnon

April 1982

Presented at the

$$
\begin{aligned}
& \text { Conf-820445--1 } \\
& \text { Conf-820324--4 } \\
& \text { Conf-820541--1 }
\end{aligned}
$$$$
\text { Automotive Technology Development }
$$$$
\text { Contractor Coordination Meeting }
$$$$
\text { Dearborn, Mich.; } 14 \text { April } 1982
$$

Biomass to Methanol Workshop

Tamarron

Durango, Colo.; 3-5 March 1982

\section{Contractor Semiannual Review Meeting}

Amfac Hotel

Burlingame, Calif.; 16-18 May 1982

Prepared Under Task No. 1265.20

WPA No. 17-349

Solar Energy Research Institute

A Division of Midwest Research institute

1617 Cole Boulevard

Goiden, Colorado 80401

Prepared for the

U.S. Department of Energy

Contract No. EG-77-C-01-4042 


\section{DISCLAIMER}

This report was prepared as an account of work sponsored by an agency of the United States Government. Neither the United States Government nor any agency Thereof, nor any of their employees, makes any warranty, express or implied, or assumes any legal liability or responsibility for the accuracy, completeness, or usefulness of any information, apparatus, product, or process disclosed, or represents that its use would not infringe privately owned rights. Reference herein to any specific commercial product, process, or service by trade name, trademark, manufacturer, or otherwise does not necessarily constitute or imply its endorsement, recommendation, or favoring by the United States Government or any agency thereof. The views and opinions of authors expressed herein do not necessarily state or reflect those of the United States Government or any agency thereof. 


\section{DISCLAIMER}

Portions of this document may be illegible in electronic image products. Images are produced from the best available original document. 
Printed in the United States of America Available from:

National Technical Information Service

U.S. Department of Commerce

5285 Port Royal Road

Springfield, VA 22161

Price:

Micrnfiç he $\$ 3.00$

Printed Copy $\$ 4.00$

\section{NOTICE}

This report was prepared as an account of work sponsored by the United States Government. Neither the United States nor the United States Department of Energy, nor any of their employees, nor any of their contractors, subcontractors, or their employees, makes any warranty, express or implied, or assumes any legal liability or responsibility for the accuracy, completeness or usefulness of any information, apparatus, product or process disclosed, or represents that its use would not infringe privately owned rights. 


\title{
DISSOCIATED METHANOL TEST RESULTS
}

\author{
Joseph G. Finegold and J. Thomas McKinnon \\ Solar Energy Research Institute \\ 1617 Cole Boulevard \\ Golden, CO 80401
}

\begin{abstract}
This paper describes the design and testing of an automotive fuel system that provides hydrogen-rich gases to an internal combustion engine by catalytically cracking, or dissociating, methanol on board the vehicle. The vaporization and dissociation of methanol absorb heat from the engine exhaust and increase the lower heating value of the fuel by approximately $22 \%$. In addition, raising the compression ratio and burning with excess air increase the engine thermal efficiency.

Engine dynamometer test results with dissociated methanol demonstrated improvements in brake thermal efficiency compared to gasoline from $30 \%$ to $100 \%$ depending on engine speed and torque. Lower speeds and torques produce the largest improvements. This paper presents maps of exhaust temperature and exhaust heat content. The exhaust temperature is almost always high enough for dissociation to occur, but at lower power outputs, there is only enough exhaust energy for partial dissociation of the methanol.
\end{abstract}

\section{INTRODUCTION}

We expect dissociated methanol to offer higher efficiency than conventional liquid fuels because of three factors: (1) the increase in chemical energy due to waste heat recovery, (2) an extended lean misfire limit, and (3) higher allowable compression ratio. Exhaust emissions also are lower.

In the past, many researchers have proposed on-board fuel processing to generate hydrogen for automotive applications (e.g., Breshears, Cotrill, and Rupe, 1974; Houseman and Voecks, 1980; Kester, Konopta, and Camara, 1975; and Sjostrom, Eriksson; and tindner, 1979). Numerous groups have constructed several experimental automobiles and performed engine tests (e.g., Noguchi and co-workers, 1977: Inagaki, Hirota, and Ueno, 1979; MacDonald, 1976; and Finegold, 1976). Only recently has dissociation of alcohol attracted.much serious attention.

Methanol can be dissociated to hydrogen and carbon monoxide or carbon dioxide by strongly endothermic reactions. The reactions occur in the $250^{\circ}-350^{\circ} \mathrm{C}$ range, which matches available waste heat in engine exhaust, increasing the enthalpy of the fuels as shown in Table 1. In terms of the energy increase, the dissociation reaction yielding carbon monoxide is more attractive than the steam reforming reaction yielding carbon dioxide. The resultant fuels also

This book was prepared as an account of work sponsored by an agency of tha United States Governmen Neither the United States Government nor any agency thereot, not any of their employees. mokes any Warrese comesents that its use woyld not infringe privately owned rights. Reference herein to any specitic commercial product, process, or service by trade name. trademark, manufocturer, or otherwise, does not necossarily constituie or imply its endorsement, recommendation, or favoring by the Unized States Gdvernnment or any agency thereot. The views and opinions of authors expressed herein do no 
Table 1. Comparison of Fuel Processing Reactions

\begin{tabular}{lc}
\hline Reaction & $\begin{array}{c}\text { Increase in Lower } \\
\text { Heating Value }\end{array}$ \\
\hline Methanol & \\
& \\
$\mathrm{CH}_{3} \mathrm{OH}+$ heat & $+2 \mathrm{H}_{2}+\mathrm{CO}$ \\
$\mathrm{CH}_{3} \mathrm{OH}+\mathrm{H}_{2} \mathrm{O}+$ heat $+3 \mathrm{H}_{2}+\mathrm{CO}_{2}$ & $15 \%$ \\
Ethanol & \\
$\mathrm{C}_{2} \mathrm{H}_{5} \mathrm{OH}+\mathrm{H}_{2} \mathrm{O}+$ heat $\rightarrow 4 \mathrm{H}_{2}+2 \mathrm{CO}_{2}$ & $20 \%$ \\
$\mathrm{C}_{2} \mathrm{H}_{5} \mathrm{OH}+3 \mathrm{H}_{2} \mathrm{O}+$ heat $\rightarrow 6 \mathrm{H}_{2}+2 \mathrm{CO}_{2}$ & $13 \%$ \\
\hline
\end{tabular}

have a higher energy density since less, or no, water is required. The steam reforming reaction has the advantage of occurring at a lower temperature $\left(\sim 200^{\circ} \mathrm{C}\right)$. Methanol has less tendency to coke (lay down carbon) on dissociation than hydrocarbon fuels do.

The methanol dissociation reaction is the reverse of the reaction by which methanol is produced. Although it is strongly endothermic, dissociation is thermodynamically favored because of an increase'in entropy, as shown by the equation for free energy:

$$
\begin{aligned}
\Delta G_{\mathrm{rXn}}=\Delta \mathrm{H}_{\mathrm{rXn}} & -\mathrm{T} \Delta \mathrm{S}_{\mathrm{rXn}}=-39.7 \mathrm{~kJ} / \mathrm{gmol} \\
\Delta \mathrm{H}_{\mathrm{rXn}} & =99.6 \mathrm{~kJ} / \mathrm{gmol} \\
\Delta \mathrm{S}_{\mathrm{rXn}} & =243 \mathrm{~J} / \mathrm{gmo1}{ }^{\circ} \mathrm{C} \\
\mathrm{T} & =300^{\circ} \mathrm{C}(573 \mathrm{~K}) \\
\mathrm{P} & =100 \mathrm{kPa}
\end{aligned}
$$

Equilibrium favors the reaction going nearly to completion. At $300^{\circ} . \mathrm{C}$ and $150 \mathrm{kPa}$, equilibrium considerations predict that $99.9 \%$ of the methanol will be converted to $\mathrm{CO}$ and $\mathrm{H}_{2}$, discounting side reactions.

In addition to the desired dissociation reaction, many side reactions are possible as shown in Table 2. Most of the side reactions are undesirable. Reactions 2 and 3 consume hydrogen that would have otherwise been available to extend the lean misfire limit. Reaction 5 produces solid carbon that would plug the catalyst bed and destroy the catalyst activity. 
Table 2. Methano1 Dissociation and Side Reactions

\begin{tabular}{ll}
\hline (1) $\mathrm{CH}_{3} \mathrm{OH}$ & $\rightarrow \mathrm{CO}+2 \mathrm{H}_{2}$ \\
(2) $2 \mathrm{CH}_{3} \mathrm{OH}$ & $+\mathrm{CH}_{3} \mathrm{OCH}_{3}+\mathrm{H}_{2} \mathrm{O}$ \\
(3) $\mathrm{CH}_{3} \mathrm{OH}+\mathrm{H}_{2}$ & $\rightarrow \mathrm{CH}_{4}+\mathrm{H}_{2} \mathrm{O}$ \\
(4) $\mathrm{CO}+\mathrm{H}_{2} \mathrm{O}$ & $\rightarrow \mathrm{CO}_{2}+\mathrm{H}_{2}$ \\
(5) $2 \mathrm{CO}$ & $\rightarrow \mathrm{C}_{2}+\mathrm{CO}$ \\
(6) $\mathrm{CH}_{3} \mathrm{OH}$ & $+\mathrm{CH}_{2} \mathrm{O}+\mathrm{H}_{2}$ \\
\hline
\end{tabular}

The choice of catalyst has a major effect on reaction kinetics and, thus, the composition of the reaction products. A number of catalysts are known to be active for methanol dissociation (e.g., platinum, palladium, copper, zinc). In addition to high activity toward dissociation at low temperatures and low activity toward side reactions, a fuel-reforming catalyst should have a low cost, long life, and be resistant to poisoning by impurities that might be present in fuel-grade methanol.

\section{SYSTEMS DESCRIPTION}

The dissociated methanol system comprises a fuel system to dissociate the methanol and a modified internal combustion engine to burn it. They are shown together in a simplified schematic drawing in Fig. $l$ and in a comprehensive one in Fig. 2 showing instrumentation loçations.

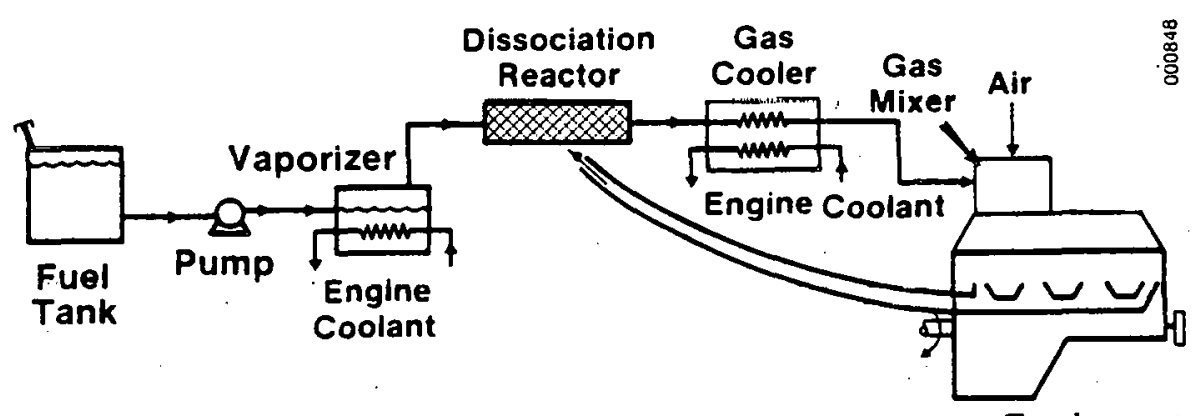

Engine

Figure 1. Conceptual Diagran of Automotive System 


\section{Fuel System}

The function of the fuel system is to vaporize and dissociate the methanol and to deliver the hydrogen-rich gases to the engine to be burned. The major components, in order of fuel flow, are the vaporizer, superheater, reactor, and gas cooler. To minimize time and cost, most of the components selected are commercially available, although some were slightly modified. All the components were sized to fit into the engine compartment of a 1980 Chevrolet Citation so the system could be road tested.

Liquid methanol is pumped by a small electric gear pump from a fuel reservoir. It then is filtered to $7 \mu \mathrm{m}$ using a series of filters. From here the methanol passes through a solenoid valve and into the vaporizer, a vertically-mounted, she11-and-tube heat exchanger with $2200 \mathrm{~cm}^{2}$ of heat transfer area. Engine coolant, which provides heat for the vaporization, flows through the tubes, and the methanol is vaporized in the shell. A cylinder is mounted directly above the vaporizer and serves as a vapor-liquid separation chamber. A level probe, operating on an electrical capacitance principle, monitors the methanol level in the vaporizer. Cycling the liquid methanol solenoid valve controls the liquid level. The engine coolant temperature and, to a lesser extent, the vaporization rate determine the vaporization pressure. Most of the testing was conducted with the engine coolant in the $90^{\circ}-100^{\circ} \mathrm{C}$ range, producing a methanol vapor pressure of $180-200 \mathrm{kPa}$.

Methanol leaves the vaporizer as saturated vapor at approximately $80^{\circ} \mathrm{C}$. It passes through a solenoid valve and into the superheater, a double-pipe heat exchanger with $880 \mathrm{~cm}^{2}$ heat transfer area that heats the methanol to approximately $250^{\circ} \mathrm{C}$ using engine exhaust after it leaves the catalytic reactor. Upon leaving the superheater, the methanol vapor enters the dissociation reactor, where the methanol vapor makes contact. with the catalyst and where heat from the engine exhaust drives the endothermic reaction. The reactor was designed, built, and tested by Cerini, Houseman, and Voecks (1980) at the Jet Propulsion Laboratory under contract with the Solar Energy Research Institute (SERI). The reactor is a stainless steel, she1l-and-tube heat exchanger, 100 $\mathrm{cm}$ long and $18 \mathrm{~cm}$ in diameter with $4.0 \mathrm{~m}^{2}$ of heat transfer area. The $0.8-\mathrm{cm}$ ID tubes are packed with catalyst pellets over which the fuel flows. The engine exhaust flows directly from the exhaust manifold to the reactor. Both fuel and the exhaust sides are two pass flow, and the flow is counter-current. The reaction occurs on the surface of a $\mathrm{Cu}-\mathrm{Z}_{\mathrm{n}} \mathrm{O}$ catalyst supported on alumina pellets, United Catalysts 非T2107RS.

The gaseous fuel, which consists of hydrogen and carbon monoxide in approximately a $2: 1$ ratio with small amounts of methanol, methane, and dimethyl ether, leaves the reactor at approximately $300^{\circ} \mathrm{C}$. Before entering the engine, the gaseous fuel is cooled to $100^{\circ} \mathrm{C}$ to improve the volumetric efficiency, lower $\mathrm{NO}_{\mathrm{x}}$ emissions, and increase resistance to preignition. The cooling is done using engine coolant from the radiator in a small shell-and-tube heat exchanger (heat transfer area $=1200 \mathrm{~cm}^{2}$ ). The decrease in temperature increases the energy density of the fuel from $5.4 \mathrm{~kJ} / \ell$ to $8.3 \mathrm{~kJ} / 2$ (methane at STP is $34.0 \mathrm{~kJ} / \ell$ ). The higher energy density of the fuel allows increased engine power output because the fractional volume required for fuel in the air-fuel mixture is reduced. 


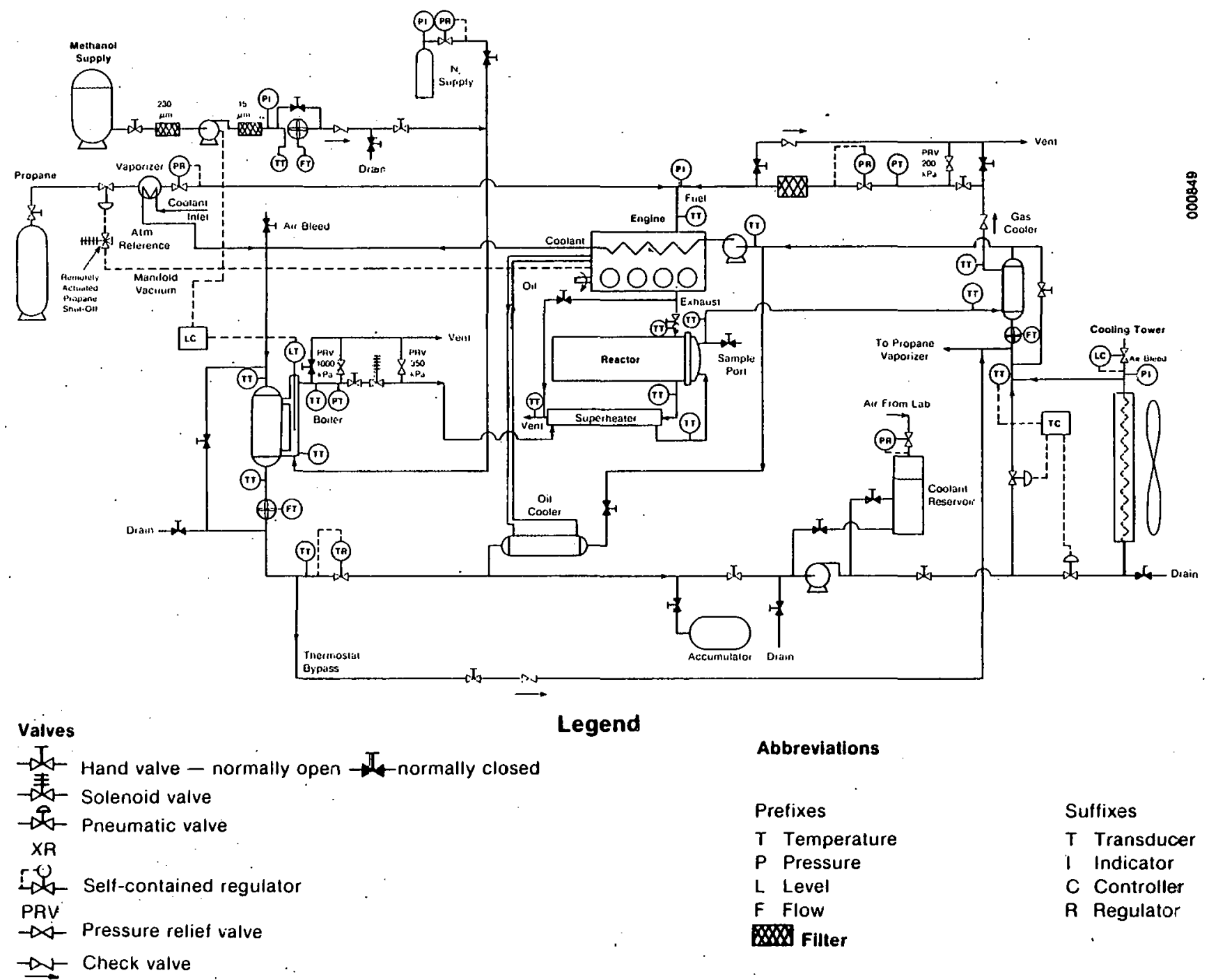

Figure 2. Detailed Scchematic of Automotive System 
A conventional gas regulator upstream of the carburetor controls pressure of this gaseous fuel. The final step in fuel processing is to filter any catalyst fines from the fuel stream to protect the engine. At this point, the carburetor can draw on a supply of cool synthesis gas at a regulated pressure.

Since the fuel processing system requires engine heat to function, a separate start-up system is required. For the test stand, propane was plumbed to the fuel line directly upstream of the carburetor. After the engine is adequately warmed up, the methanol flow is started and the propane flow shut off. A liquld methanol fuel injection system is being installed in the vehicle for startup.

\section{Engine}

We used a General Motors 2.5-l, In-11ne, four-cylinder engine rated at $65 \mathrm{~kW}$ from a 1980 Chevrolet Citation. The block and cross-flow head are cast iron. The high energy ignition system was used. The engine was modified only slightly to operate on dissociated methanol. The compression ratio was increased. from the stock $8.3: 1$ to approximately $14: 1$ by installing flat-top pistons with greater compression height and by milling $1.5 \mathrm{~mm}$ from the cylinder head. The original carburetor was replaced with an Impco air-valve carburetor, Model 225, designed for propane. No changes were made to valve timing, but we removed the exhaust gas recirćulation, exhaust air injection equipment, and the exhaust catalyst.

\section{RESULTS}

Figures 3 and 4 show the engine maps for the baseline gasoline engine and the dissociated methanol system, respectively. Note that the peak efficiency for

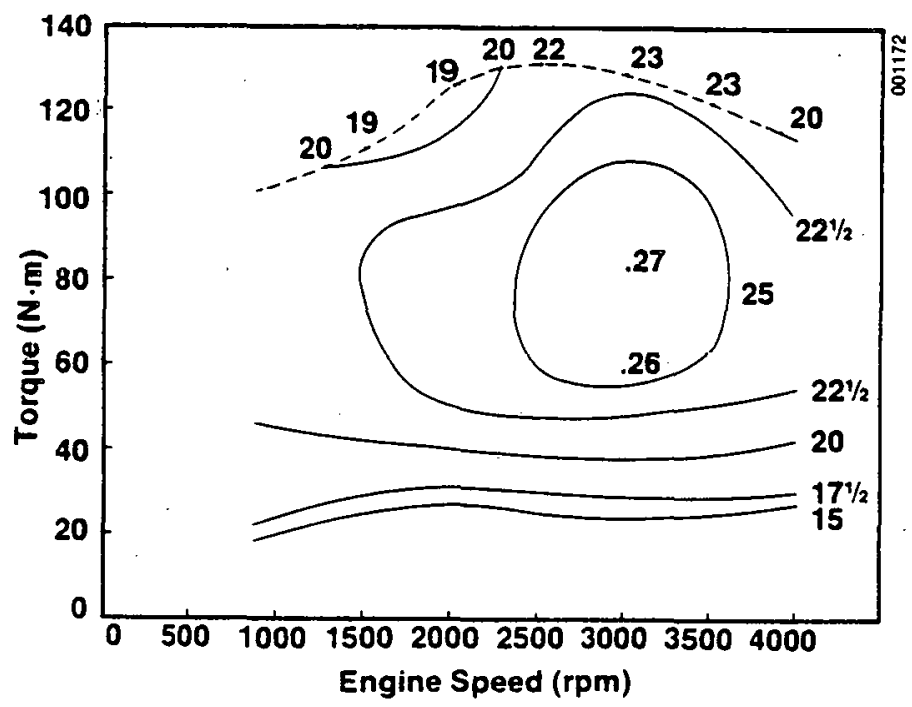

Isopleths of Constant Brake

Thermal Efficiency (\%)

Maximum Torque Curve

Gasoline Baseline

Figure 3. Gasoline Engine Map 


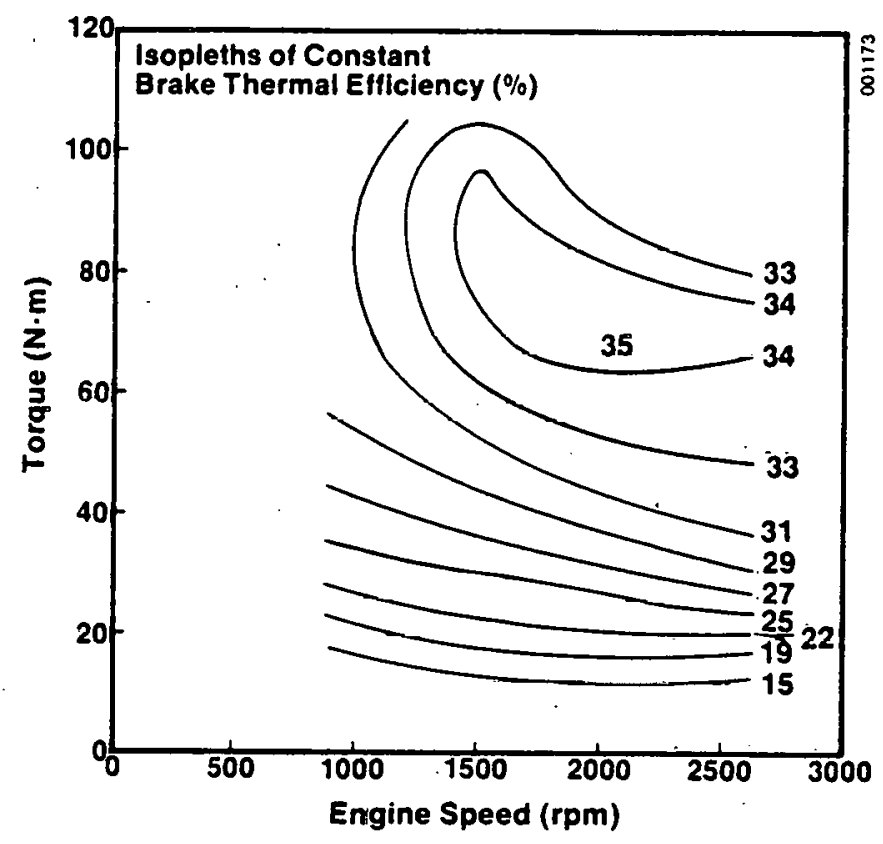

Figure 4. Dissociated Methanol Engine Map

the gasoline system is $27 \%$ and for the methanol system, $35 \%$. The peak efficiency for methanol occurs at a lower speed.

Figures 5 and 6 present brake thermal efficiency compared to torque at 1000 and $2000 \mathrm{rpm}$, respectively, for both the gasoline system and the dissociated

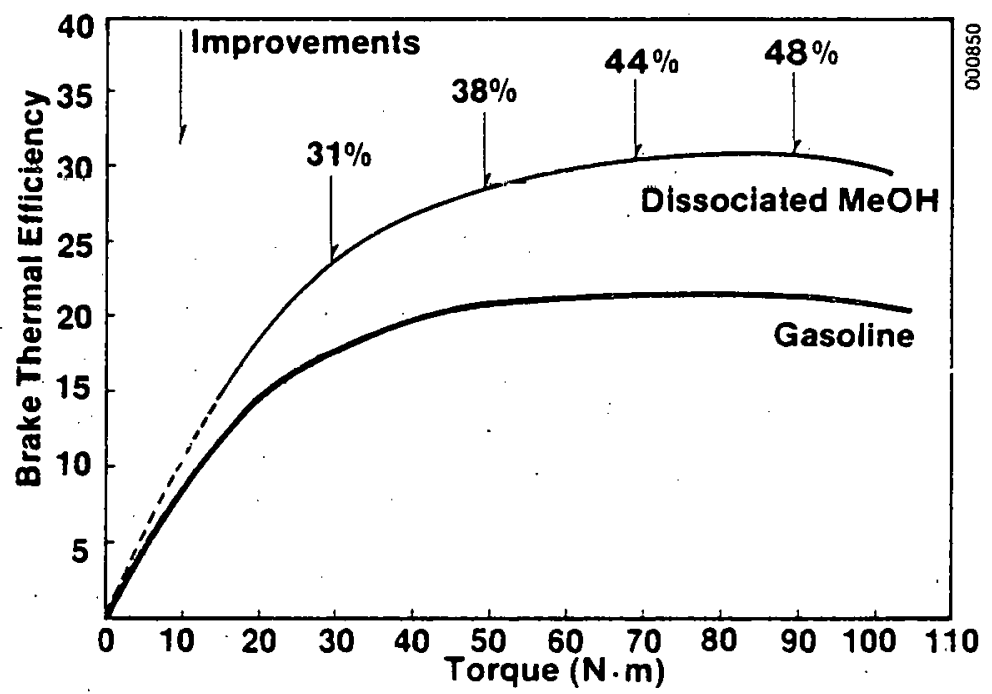

Figure 5. Brake Thermal Efficiency vs. Torque at 1000 rpm 


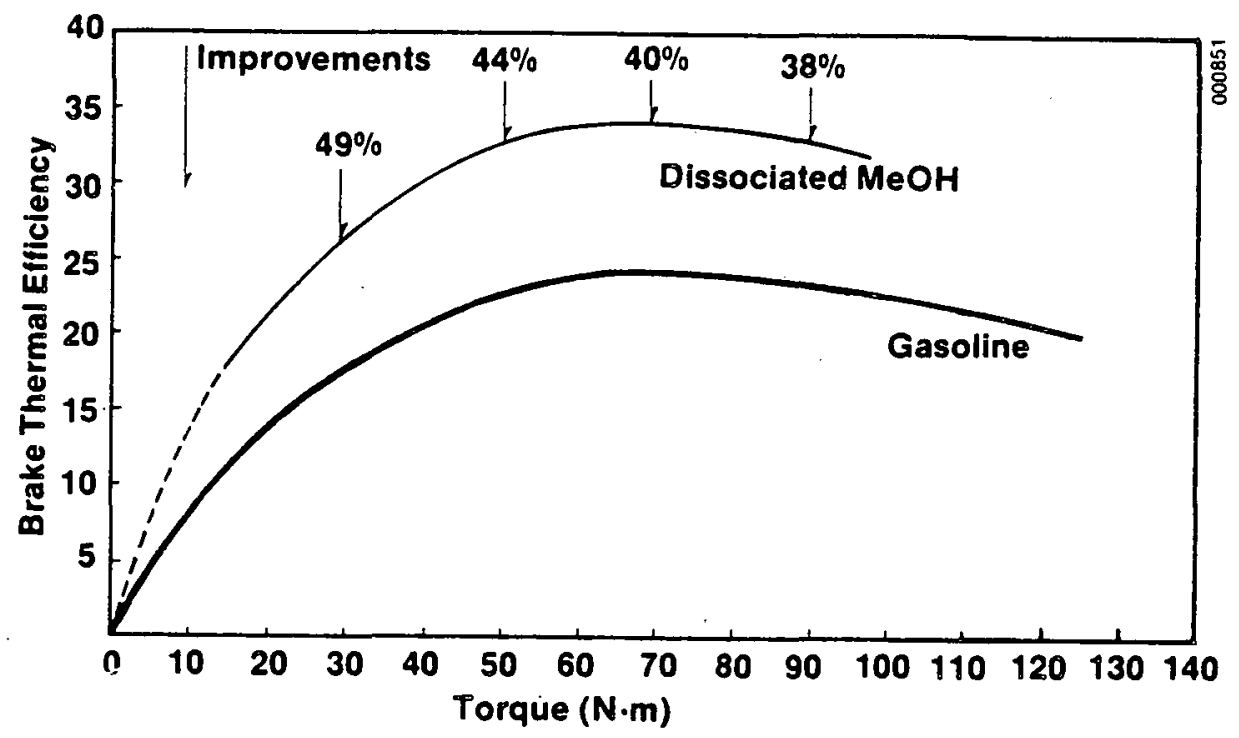

Figure 6. Brake Thermal Efficiency vs. Torque at $2000 \mathrm{rpm}$

methanol system. The improvement is in the range of $31 \%$ to $48 \%$ at $1000 \mathrm{rpm}$ and from $38 \%$ to $49 \%$ at $2000 \mathrm{rpm}$.

Figures 7 and 8 show maps of exhaust temperature and exhaust heat content re1ative to that required for $100 \%$ dissociation of the inlet methanol. With the $\mathrm{Cu} / \mathrm{ZnO}_{\mathrm{n}}$ catalyst, the effective lower temperature limit for reaction is $250^{\circ}-$ $300^{\circ} \mathrm{C}$, At the lnwer pnwer points, tho errhauot temperature dul lied concent are only high enough to dissociate part of the methanol. In practice, this is not a problem. Even with a small fraction of the methanol dissociated, there is enough hydrogen generated to gain the desired lean-burn advantages. Some of the possible chemical energy gain, however, is not realized.

\section{DISCUSSION}

The data presented in the previous section shows substantial improvements in brake thermal efficiency for the dissociated methanol system when compared to the gasoline system. We attribute the improvements to three basic differences: (1) the chemical energy increase of the fuel resulting from the vaporization and subsequent catalytic dissociation of methanol into hydrogen and carbon monoxide; (2) the increase in engine efficiency resulting from the use of a very high compression ratio; and (3) the use of very low equivalence ratios.*

*Equivalence ratio $(\phi)$ is the actual fuel/air ratio divided by the stoichiometric fuel/air ratio. It is the inverse of the excess air ratio $(\lambda)$. 
The chemical energy increase of the fuel is greatest under high loads when the most thermal energy is present in the exhaust. Despite this, the improvements relative to gasoline are greatest under low loads.

The increased compression ratio is made possible by the high resistance to preignition of the hydrogen-rich fuel. High compression ratios (expansion ratios) allow more work to be extracted from a given charge on the expansion stroke, thus increasing the thermodynamic efficiency. The magnitude of the increase may be estimated from the equation for air-standard cycle efficiency:

$$
n=1-\left(\frac{1}{\mathrm{CR}}\right)^{\gamma-1}
$$

where

$$
\begin{aligned}
\eta & =\text { thermal efficiency } \\
\mathrm{CR} & =\text { compression ratio } \\
\gamma & =\text { ratio of specific heats }\left(C_{p} / C_{v}\right)
\end{aligned}
$$

Exc̈ess air combustion causes higher thermal efficiency for several reasons: reduced throttling losses, cooler combustion temperatures, and decreased heat capacity of the combustion products. Excess air combustion is possible because of the wide flammability limits of hydrogen, the major constituent of the fuel. The optimum equivalence ratio was as low as $\phi=0.3(\lambda=3.3)$ depending on engine speed and load.

Throttling losses are reduced in a lean-burn engine because manifold pressures are much higher for a given power output; thus, the engine does not need to expend as much shaft power in pumping the air/fuel mixture into the cylinders. For example, a 2.5-l engine operating at $2500 \mathrm{rpm}$ with a manifold pressure of $70 \mathrm{kPa}$ (9-in. Hg vacuum) wastes approximately $1 \mathrm{~kW}$ of shaft power pumping air across the partially closed throttle. An engine fueled with hydrogen or hydrogen-rich gases can operate under most conditions with the throttle almost or completely wide open. Power is modulated by controlling fuel flow once wide-open throttle at low equivalence ratios is attained.

Low equivalence ratios reduce peak combustion temperatures because of the di1uent effect of the excess air. The most obvious effect is that heat losses to the cylinder walls are lowered, allowing more heat to be converted to work. Two more subtle effects are changes in heat capacity with temperature and dissociation of water and carbon dioxide at high temperature. For example, from $100^{\circ}$ to $2500^{\circ} \mathrm{C}$ the $C_{v}$ of water vapor increases $55 \%$. The result is that a given amount of heat increases combustion temperatures more at a lower tenperature and, thus, is more effective. High combustion temperatures cause a fraction of the water vapor and carbon dioxide to endothermically dissociate at the start of the expansion stroke, absorbing some of the energy of combustion. The water vapor and carbon dioxide recombine and release the energy, but it is released later in the expansion stroke where it is less effective. The dissociation is a very strong function of temperature and pressure. 


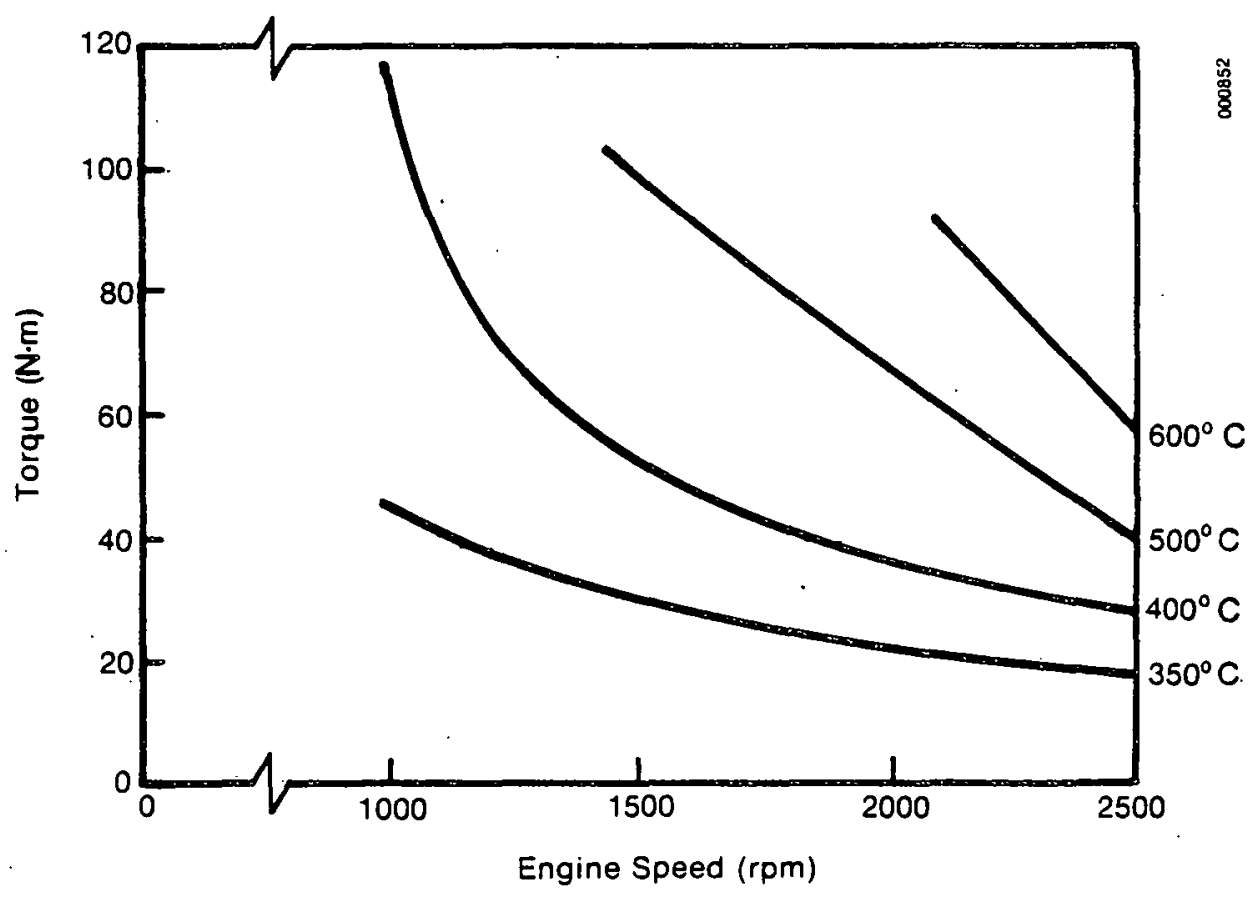

Figure 7. Exhaust Temperature Map

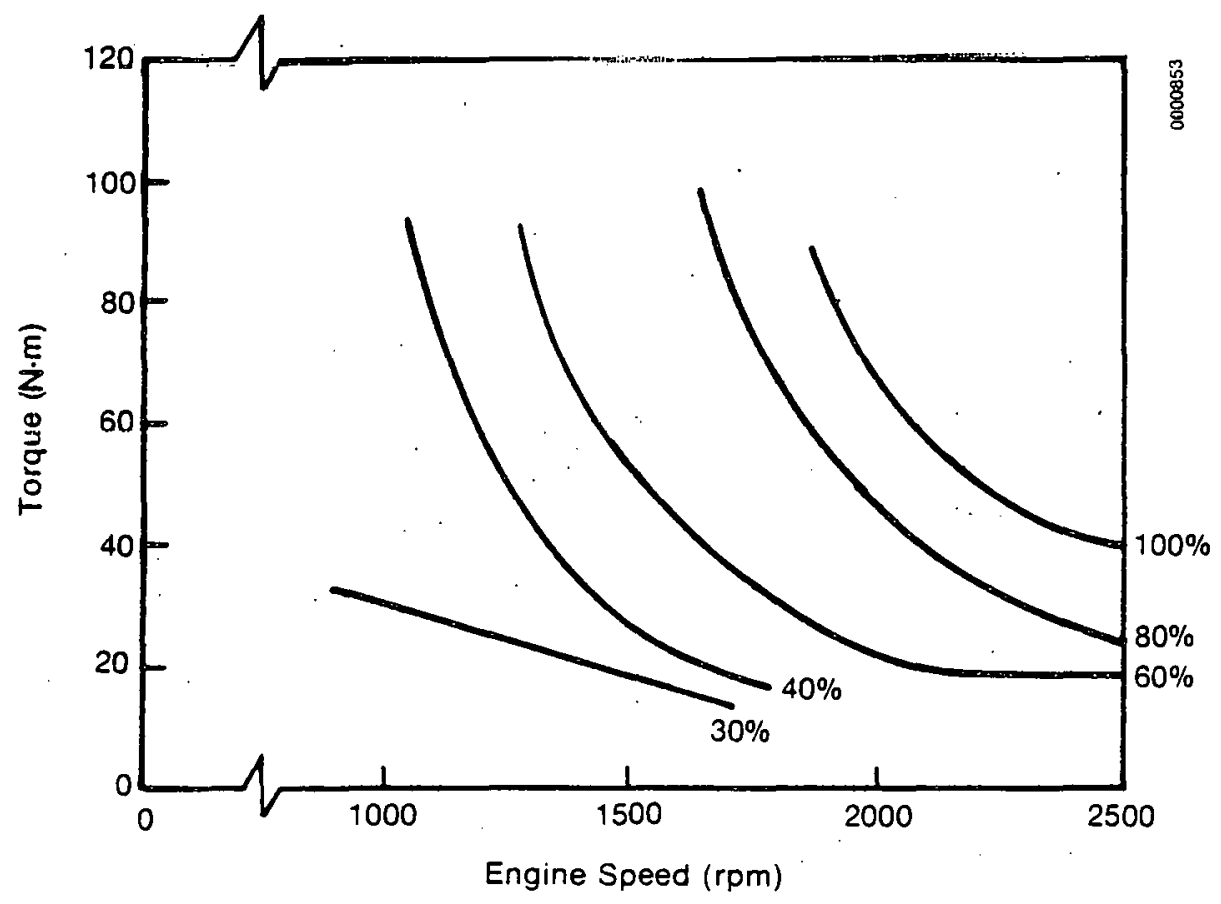

Figure 8. Percentage of Fuel Methanol That Can Be Dissociated with Exhaust Heat 
The heat capacity of the combustion products of a lean-burn engine is further reduced because alr has a lower heat capacity than water and carbon dioxide. This allows higher combustion temperatures for a given heat input. Equation 2 also shows this effect since $\gamma$ increases as $C_{v}$ decreases.

The power of the dissociated methanol engine was comparable to the gasoline engine at low engine speeds. The energy density of the fuel is approximately one-fourth that of methane and one-tenth that of propane, but less air is required to burn the dissociated methanol. Thus, the energy density of the air/fuel mixture is approximately the same for all these gaseous fuels and is about $10 \%$ less than gasoline/air mixtures. The increased compression ratio brings the power of gasoline and dissociated methanol engines to about the same level.

\section{VEHICLE INSTALLATION}

The entire system was installed in the engine compartment of the Citation for road testing and EPA emissions testing. The methanol vaporizer was replaced with a shell-and-tube heat exchanger with $3300 \mathrm{~cm}^{2}$ of heat transfer area, $50 \%$ larger than the original one, allowing the coolant thermostat setting to be lowered to $\sim 85^{\circ} \mathrm{C}$. The methanol vaporizes in the shell, and the coolant flows in a two-pass configuration in the tubes. The heat exchanger is mounted vertically as was the one on the test stand. A larger capacity filter with a more favorable shape for vehicle installation was used. The fuel regulator was replaced with a larger capacity one to allow more precise pressure regulation. No muffler is used on the vehisle as the reactor adequately silenced exhaust noise.

\section{SUMMARY}

A dissociated methanol fuel system was designed, built, and tested. Improvements in the brake thermal efficiency of $30 \%-100 \%$ over gasoline were obtained from engine dynamometer tests even though the fuel generally did not completely dissociate. Vehicle tests are currently underway, and we are designing a second generation system to solve the problems encountered in the first system and to explore the benefits of desigu improvements.

\section{ACKNOWLEDGMENTS}

Many people at SERI performed the work on this project. We especially want to thank current team members: Mark Sorency, Gerard Glinsky, Steve Rummel, Ed Gostling, Mike Karpuk, Mark Blakeslee, and Dan Sçhell for their contributions. Dr. R. Passamaneck was responsible for the engine dynamometer testing of the dissociated methanol system. Dr. C. S. Smith is acknowledged for providing the management environment that stimulated this work. This work was funded by the Office of Alcohol Fuels, U.S. Department of Energy. 


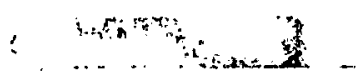

$x^{\prime}$

\section{REFEREMCES}

Breshears, R., H. Cotrill, and J. Rupe (1974). Hydrogen injection for internal combustion engines. Presented to Council on Environmental Quality Advisory Committee on Alternative Power Systems. Ann Arbor, Michigan.

Cerini, D., J. Houseman, and G. Voecks (1980). Operation of a catalytic methanol decomposition reactor for vehicular use. Proceedings of the 4 th International Symposium on Alcohol Fuels Technology, Guaruja, Brazil.

Finegold, J. G. (1976). Hydrogen: primary or supplementary fuel for automotive engines. SAE \#760609, Society of Automotive Engineers West Coast Meeting.

Houseman, J. and G. E. Voecks (1980). Hydrogen engines based on liquid fuels, a review. Third World Hydrogen Energy Conference Proceedings, Tokyo, Japan.

Inagaki, T., T. Hirota, and Z. Ueno (1979). Combustion and emission of gaseous fuel from reformed methanol in automotive engines. Alcohol Fuels Technology 3rd International Symposium Proceedings, Asilomar, California.

Kester, F. L., A. J. Konopta, and E. H. Camara (1975). On-board steamreforming of methanol to fuel the automotive hydrogen engine. IECEC 1975 Record, 1176-1183.

Mac̈Donald, J. S. (1976). Evaluation of the hydrogen-supplemented fuel concept with an experimental multicylinder engine. SAE No. 760101.

Noguchi, M., T. Bunda, M. Sumiyoshi, J. Kageyama, and S. Yamaguchi (1977). A study on reformed fuel for an automotive gasoline engine. NATO/CCMS 4 th International Symposium on Automotive Propulsion Systems, Washington, D.C.

Sjostrom, K., S. Eriksson, and B. Lindner (1979). Hydrogen-fuel for tomorrow today. First International Automotive Fuel Economy Research Conference Proceedings, Arlington, Virginia. 